\title{
Allergic Contact Dermatitis Caused by Homemade Slime
}

\author{
Bisera KOTEVSKA TRIFUNOVA'1, Zdravka V. DEMERDJIEVA', Nikolay K. TSANKOV'1, \\ Jana S. KAZANDJIEVA²
}

${ }^{1}$ Acibadem - City Clinic - Tokuda hospital

${ }^{2}$ Department of Dermatology and Venereology, Medical University, Sofia

*Correspondence: Bahram Nikkhoo, E-mail: Dr.b.nikkhoo@gmail.com

UDC 616.5-002.1-053.2:613.63

\begin{abstract}
Nowadays, allergic reactions in children are seen in dermatological practice on a daily basis. The most common reasons for allergic contact dermatitis (ACD) are piercings, temporary tattoos, a wide range of cosmetic products, substances related to the practice of a variety of hobbies and sports, etc. Slime is a new hobby and has become an obsession for some kids. There are many homemade slime recipes. The most common recipe for slime is glue, borax and food coloring for all kinds of rainbow effects. We present a case of an 11-year-old Caucasian girl with hand contact dermatitis caused by an allergic reaction to Slime.
\end{abstract}

Key words: Dermatitis, Contact; Play and Playthings; Safety; Child; Borates; Adhesives; Food Coloring Agents Non MeSH: Slime

The frequency of allergic contact dermatitis (ACD) worldwide is reported to be between 15 and $71 \%$. In Bulgaria it is around $42 \%$ (according to the author's data gathered between 2013 and 2017 in 78 children in whom patch test had been performed). Kazandjieva J. Masterclass Pediatric dermatology Sofia 3-6.06.16.

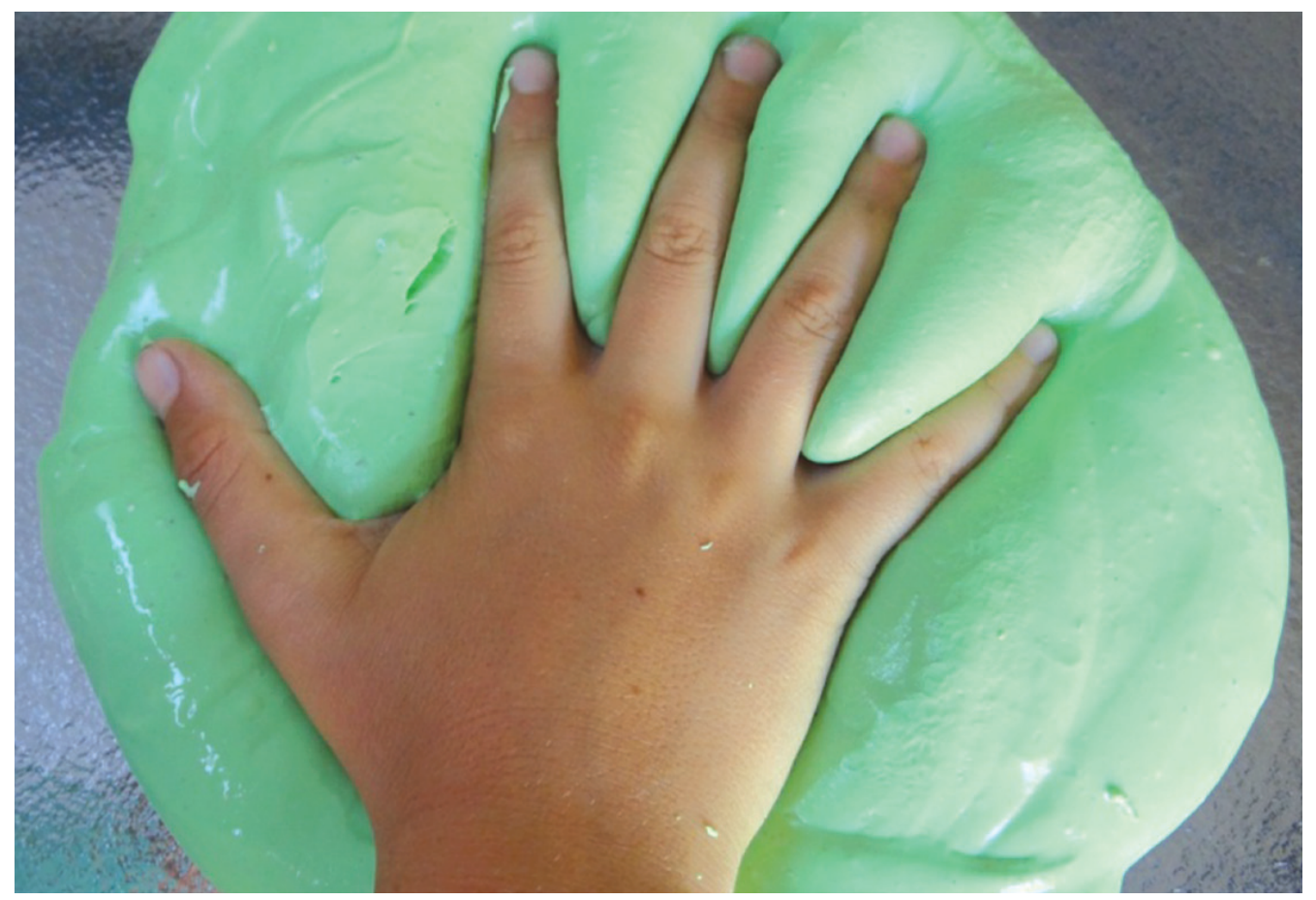

Figure 1. Homemade Slime 


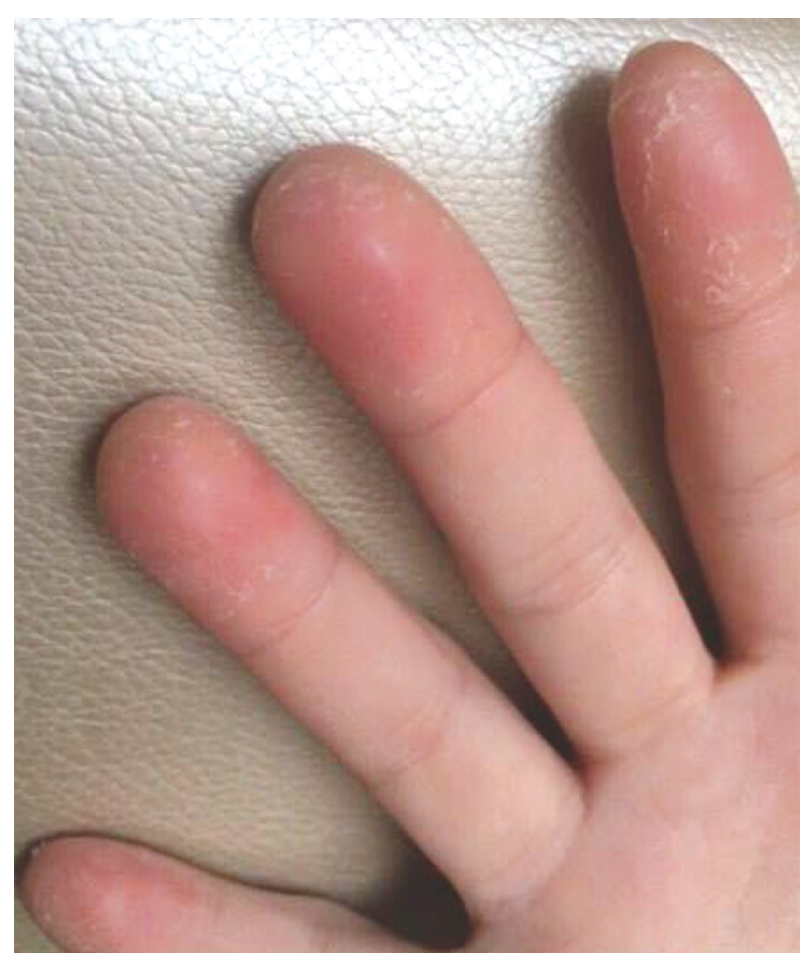

Figure 2. Contact dermatitis on the fingers

Nickel, cobalt, Balsam of Peru and parafenilendiamina were the most frequent sensitizers.

In recent years, there has been a significant increase in the frequency of ACD in children that is possibly related to the prolonged contact with allergic substances inherent to different hobbies in everyday life.

\section{Case Report}

An 11-year-old female patient presented with suddenly appearing itchy rash on the palms and fingers. The patient and her mother associated the appearance of the rash with her new hobby, making a slime (Figure 1).

The treatment with a wide range of topical corticosteroids yielded good results.

On clinical examination, the skin changes were localized on both hands. Erythema and desquamation were present (Figures 2 and 3 ).

Routine laboratory findings were within the normal ranges. The microbiological and mycological examinations were negative.

Patch testing with European baseline series (Chemotechnique Diagnostics) was performed. Positive reactions to Kathon $(+++)$,

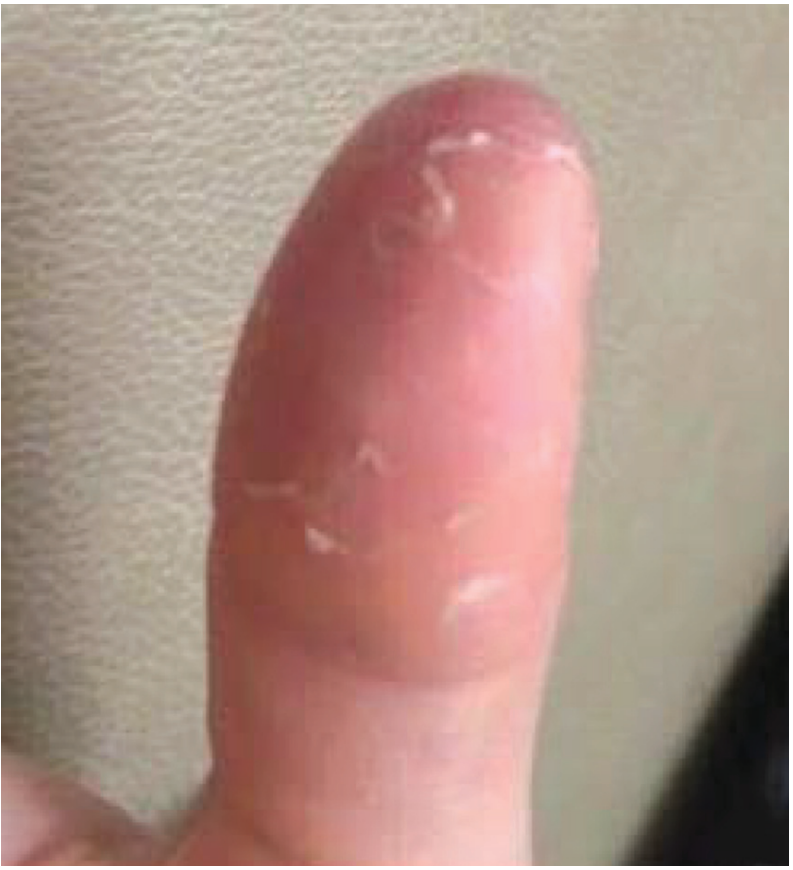

Figure 3. Erythema and desquamation on the finger

and Methylisothiazolinone $(++)$, were detected (Figure 4).

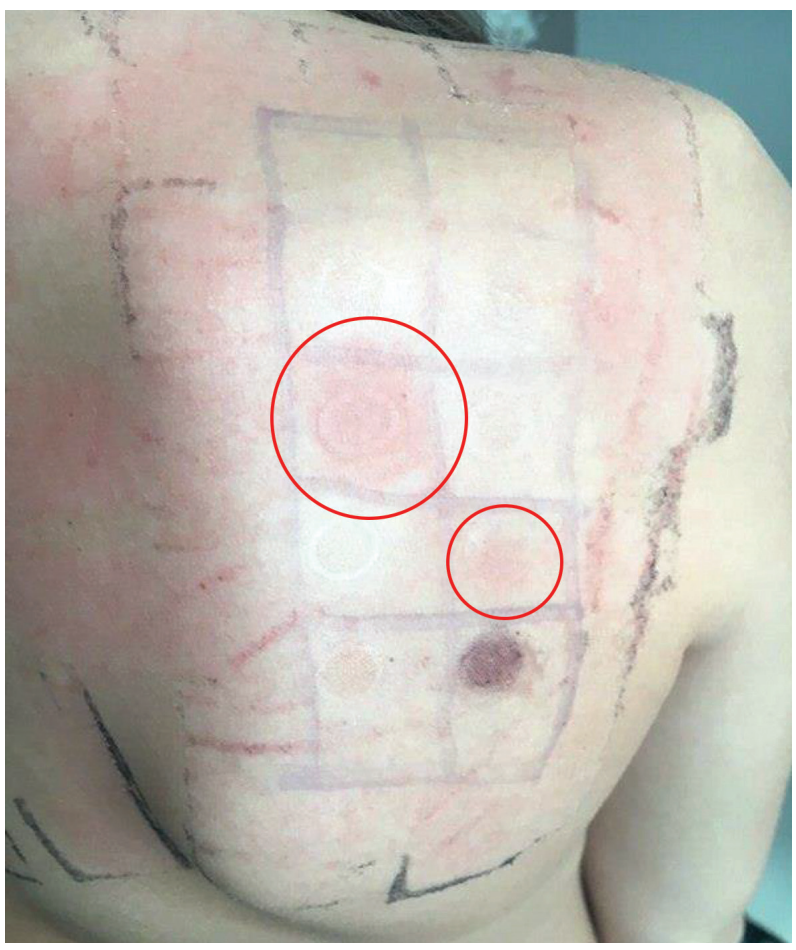

Figure 4. Positive reactions to Kathon $(+++)$, and Methylisothiazolinone $(++)$ 


\section{Discussion}

Slime is a new hobby and has become an obsession for some kids. There are many different types of slime (Soft Serve, Fluffy Slime, Clear Slime, Foam, etc.)

The most common recipe for homemade slime is glue, borax and food coloring.

Our patient made her slime with borax and glue without color.

We reviewed the literature looking for the main ingredients glue and Borax, and we found that the glue, which had been used by our patient, contained Methylisothiazolinone.

Boric acid and Sodium borate (Borax) are used in household cleaning, in many detergents, cosmetics, and enamel glaze $(1,2)$.

Literature offers a lot of reports on boric acid toxicity and fatalities (3). The main symptoms from Borax poisoning are vomiting, diarrhea, seizures, skin erythema looking like "boiled lobster", and extensive desquamation after a few days $(4,5)$. There are many reported cases about toxicity, but there is no evidence about skin allergy reactions to Borax.

Methylisothiazolinone (MI) has been commonly used as an antimicrobial and antifungal preservative in different cosmetics, household products, such as moist wipes, shampoos, cleaners $(6,7)$. As a mixture, Kathon $^{\text {TM }}$ CG (methylchloroisothiazolinone/MI) is also used in paints, glues, washing tanks and adhesives $(8,9)$.

Nowadays, $\mathrm{Ml}$ is one of the most common causes of allergic contact dermatitis, because it is actually present in the most used preservatives.(10). The frequency of contact allergy to $\mathrm{MCl} / \mathrm{MI}$ and $\mathrm{MI}$ is decreasing $(11,12)$.

The Slime is usually used by young children, and it may be good to know that its main ingredients, glue and Borax, are toxic and can cause allergic reactions on the skin.

\section{Conclusion}

According to our knowledge this is the first reported case of contact dermatitis caused by Slime.

$\mathrm{Ml}$ is one of the most common causes of allergic contact dermatitis. In recent years, there has been a significant increase in the frequency of ACD in children, and some of the reasons are new hobbies, involving homemade products.

\section{References}

1. Ogg CL, Hygnstrom JR, Alberts CA, Bauer EC. Managing the risk of pesticide poisoning and understanding the signs ans symptoms [Internet]. 2012 Lincoln, NE, United States: The Board of Regents of the University of Nebraska; 2012 [revised 2018 Jun; cited 2018 Aug 15]. Available from: http://extensionpublications.unl. edu/assets/pdf/ec2505.pdf.

2. Hamilton RA, Wolf BC. Accidental boric acid poisoning following the ingestion of household pesticide. J Forensic Sci. 2007;52(3):706-8.

3. Goldbloom R, Goldbloom A. Boric acid poisoning; report of four cases and a review of 109 cases from the world literature. J Pediatr. 1953;43(6):631-43.

4. Wong IC, Heimbach MD, Truscott DR, Duncan BD. Boric acid poisoning report of 11 cases. Can Med Assoc J. 1964;90:1018-23.

5. O'Sullivan K, Taylor M. Chronic boric acid poisoning in infants. Arch Dis Child. 1983;58(9):737-9.

6. Fewings $\mathrm{J}$, Menné T. An update of the risk assessment for methylchloroisothiazolinone/methylisothiazolinone $(\mathrm{MCl} / \mathrm{MI})$ with focus on rinse-off products. Contact Dermatitis. 1999;41(1):1-13.

7. Capkin E, Ozcelep T, Kayis S, Altinok I. Antimicrobial agents, triclosan, chloroxylenol, methylisothiazolinone and borax, used in cleaning had genotoxic and histopathologic effects on rainbow trout. Chemosphere. 2017; 182:720-9.

8. Isaksson M, Gruvberger B, Bruze M. Occupational contact allergy and dermatitis from methylisothiazolinone after contact with wallcovering glue and after a chemical burn from a biocide. Dermatitis. 2004;15(4):201-5.

9. Bennike NH, Johansen JD, Zachariae C. Please, label the label; case report of occupational allergic contact dermatitis caused by methylisothiazolinone in adhesive labels. Contact Dermatitis. 2016;75(5):314-5.

10. Rodrigues-Barata AR, Conde-Salazar L. Methylisothiazolinone and methylchloroisothiazolinone: new insights. European Medical Journal. Dermatology. 2014;2(1):101-5.

11. Urwin R, Craig S, Latheef F, Wilkinson M. Methylisothiazolinone: the epidemic is declining - but not gone. Contact Dermatitis. 2017;76(9):301-2.

12. de Unamuno B, Zaragoza Ninet V, Sierra C, de la Cuadra J. Descriptive study of sensitization to methylchloroisothiazolinone and methylisothiazolinone in a skin allergy unit. Actas Dermosifiliogr. 2014;105(9):854-9. 


\section{Alergijski kontaktni dermatitis izazvan „Ijigavcem” naprav- ljenim u kućnim uslovima}

\section{Sažetak}

Danas se alergijske reakcije kod dece viđaju u svakodnevnoj dermatološkoj praksi. Najčešći uzroci alergijskog kontaktnog dermatitisa su pirsing, privremene tetovaže, širok spektar kozmetičkih proizvoda, supstance povezane sa raznim hobijima i sportovima itd. Ljigavac je novi hobi i postao je prava opsesija kod neke dece.
Ima mnogo recepata da se napravi ljigavac kod kuće. Najčešći recept za ljigavca je lepak, boraks i prehrambena boja za sve vrste efekta duge. Prikazujemo slučaj devojčice, belkinje, stare 11 godina sa kontaktnim dermatitisom na ruci izazvanim alergijskom reakcijom na ljigavca.

Ključne reči: Kontaktni dermatitis; Igra i igračke; Bezbednost; Dete; Borati; Adhezivi; Boje za hranu $\mathrm{Ne} \mathrm{MeSH}$ : Ljigavac

Received 6 September, 2018

Accepted 29 October, 2018 